\title{
Reviewing effectiveness of ankle assessment techniques for use in robot- assisted therapy
}

\author{
Mingming Zhang, Eng MSc; ${ }^{1}$ T. Claire Davies, PEng, PhD; ${ }^{1-2}$ Yanxin Zhang, Eng PhD; ${ }^{3}$ Shane Xie, Prof Eng PhD ${ }^{1^{*}}$ \\ Departments of ${ }^{1}$ Mechanical Engineering, ${ }^{2}$ Surgery, and ${ }^{3}$ Sport and Exercise Science, University of Auckland, \\ Auckland, New Zealand
}

\begin{abstract}
This article provides a comprehensive review of studies that investigated ankle assessment techniques to better understand those that can be used in the real-time monitoring of rehabilitation progress for implementation in conjunction with robot-assisted therapy. Seventy-six publications published between January 1980 and August 2013 were selected based on eight databases. They were divided into two main categories (16 qualitative and 60 quantitative studies): 13 goniometer studies, 18 dynamometer studies, and 29 studies about innovative techniques. A total of 465 subjects participated in the 29 quantitative studies of innovative measurement techniques that may potentially be integrated in a real-time monitoring device, of which 19 studies included less than 10 participants. Results show that qualitative ankle assessment methods are not suitable for real-time monitoring in robot-assisted therapy, though they are reliable for certain patients, while the quantitative methods show great potential. The majority of quantitative techniques are reliable in measuring ankle kinematics and kinetics but are usually available only for use in the sagittal plane. Limited studies determine kinematics and kinetics in all three planes (sagittal, transverse, and frontal) where motions of the ankle joint and the subtalar joint actually occur.
\end{abstract}

Key words: ankle measurement, ankle stiffness, clinical effectiveness, disability assessment, qualitative assessment, quantitative assessment, range of motion, rehabilitation device, reliability, robot-assisted therapy.

\section{INTRODUCTION}

Ankle injuries are very common both in sports and daily life [1-5]. In New Zealand, about 100,000 claims related to ankle sprains were made to the Accident Compensation Corporation in 2000 and 2001 at a cost of an estimated 31.8 million New Zealand dollars [6]. From 2002 to 2006, a total of 82,971 ankle sprains were identified in the National Electronic Injury Surveillance System database, and an estimated 2.15 ankle sprains occurred per 1,000 person-years in the United States [7]. Neurologic injuries such as stroke and spinal cord injuries also cause various ankle problems [8-9]. Ankle injuries cause complications such as edema, disuse atrophy, and arthrosis unless treated properly [10]. Additional symptoms usually include chronic pain, reduced range of motion (ROM), weak strength, and increased joint stiffness, as well as severe functional limitations $[5,11]$.

Clinicians often use a qualitative assessment method to assess ankle impairment based on a predefined scoring

\footnotetext{
Abbreviations: $3 \mathrm{D}=$ three-dimensional, $\mathrm{CAI}=$ chronic ankle instability, FAAM $=$ Foot and Ankle Ability Measure, FADI = Foot and Ankle Disability Index, FFI $=$ Foot Function Index, IAROM = Iowa Ankle ROM, ID-BM = inverse dynamics based method, JOA scale = Japanese Orthopedic Association's foot rating scale, MSE = manual spasticity evaluator, $\mathrm{PT}-\mathrm{BM}=$ potentiometer and torquemeter based method, $\mathrm{ROM}=$ range of motion.

*Address all correspondence to Shane Xie, Prof Eng PhD; Room 401.1004, Department of Mechanical Engineering, Auckland University, 20 Symonds St, Auckland 1142, New Zealand; +64-9-373-7599; fax: +64-9-373-7479. Email: s.xie@auckland.ac.nz http://dx.doi.org/10.1682/JRRD.2013.03.0066
} 
system. When quantitative methods are undertaken, these most commonly include the use of a goniometer or dynamometer. The goniometer is a tool to assess ankle ROM [12-13] and the dynamometer is usually used to assess ankle strength [14-15]. Other devices have been developed for measuring ankle stiffness, for monitoring the progress of a rehabilitation program, or for tracking changes in joint stiffness [16-17]. These measurement tools can guide clinicians in determining the most effective intervention.

There have also been significant advances in robotic rehabilitation in an effort to reduce the strain on the clinician. Various robot-assisted ankle rehabilitation devices have been developed in recent years [18-23]. They usually lack the function of real-time ankle assessment that should be included in a robot-assisted ankle rehabilitation program to allow the robot to adjust the control strategy for a specific rehabilitation stage. Having a better understanding of the clinical tools that are most effective in providing intervention and how they might provide quantitative inputs for robot-assisted ankle rehabilitation is necessary to develop a robotic rehabilitation device that engages all users.

This review seeks to critically compare various published studies in terms of the development, application, reliability, and validity of existing ankle measurement devices and techniques. It will provide a better understanding of the requirements for a real-time assessment strategy implementable within a robot-assisted rehabilitation program that can be used throughout the rehabilitation process.

\section{METHODS}

\section{Search Strategy}

Only English-language articles published from January 1980 to August 2013 were searched in the following six databases: Scopus, Web of Science, ScienceDirect, Academic Search Premier, Embase, and MEDLINE (OvidSP). The search terms were "Ankle*" AND "Performance OR Function OR Disabilit* OR Disorder* OR Injur* OR Spastic* OR Stabilit* OR Stiff* OR Torque OR Moment OR Strength OR Kine* OR Dynamic* OR Dorsiflexion" AND "Evaluat* OR Assess* OR Measur* OR Examinat*." Additional searches in Google Scholar and SpringerLink were further conducted for the latest studies as an important supplement. Valuable references listed in relevant publications were also screened.

A total of 411 articles were identified initially. The first two rounds of screenings were conducted based on titles and abstracts, respectively. Studies considered to meet the predefined inclusion criteria were included in the final analysis and the others were excluded. Discussion among authors resulted when inclusion of certain articles was questionable. The Figure describes the selection process.

\section{Inclusion and Exclusion Criteria}

This study aims to review existing ankle assessment techniques that can provide necessary information to allow for an evaluation of improvement during ankle exercises that are implemented using robot-assisted rehabilitation. The review attempts to better understand all methods of evaluation, including qualitative and quantitative assessment of ankle recovery level. Articles involving ankle performance or functional qualitative assessment methods such as the Foot Function Index (FFI) and Foot and Ankle Disability Index (FADI) were included. All quantitative studies assessing ankle performance or function (including ankle disability level, kinematics, and kinetics) were included. All articles had to include trials involving either normal ankle or injured
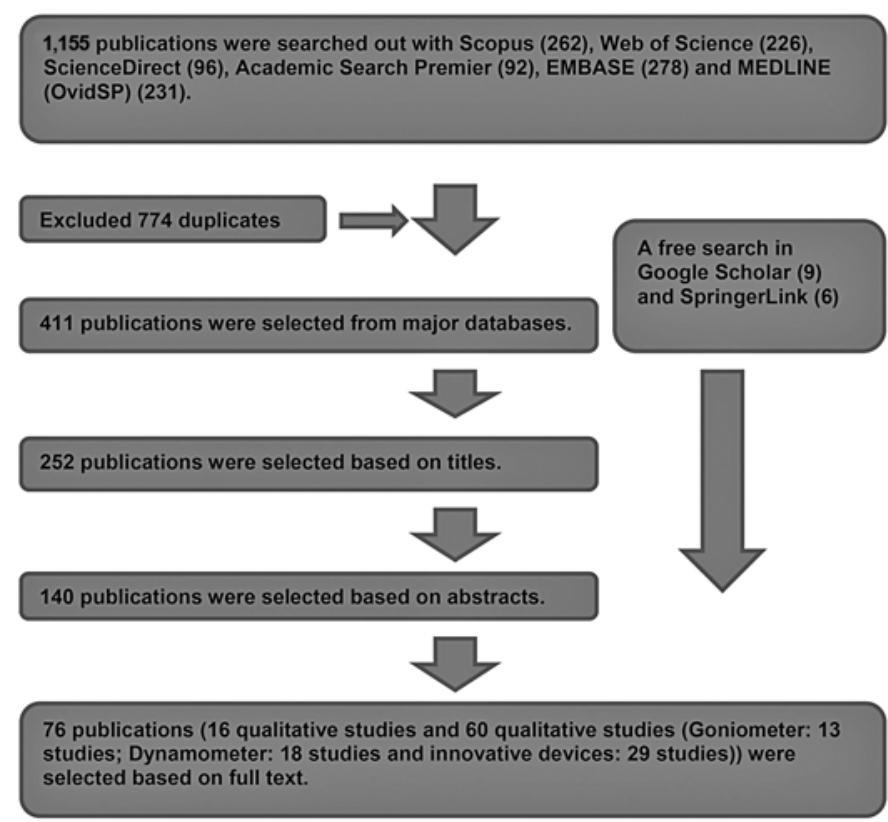

Figure.

Flow diagram of selection process for final review. 
ankle. Trials assessing animal ankle performance or function were excluded due to significant differences between the animal ankle and the human ankle. Studies involving management or identification of ankle injuries and those related to emergencies were excluded, as were invasive ankle measurement techniques. Observation-based physiological assessment techniques were excluded due to unreliable accuracy [24]. Image-based methods were also excluded because they cannot be used to evaluate functional improvement in ankle injury in combination with robot-assisted therapy. Image-based techniques that examine kinematics in vivo such as magnetic resonance imaging, computed tomography, and X-ray tend to be expensive and not implementable in a typical robotic system, though they can be used for identification of ankle injury [25-26]. In this review, we do not seek to comment on the ability to detect ligament tears (it is assumed that the correct identification of ankle injury has already occurred) but rather to examine the functional improvement before, during, and after rehabilitation interventions. The data extraction was applied in a similar way as another review conducted by Zhang et al. [27].

\section{RESULTS}

After excluding studies involving invasive measurement techniques [28-30], animal-based methods [3132], image-based methods [25-26,33-35], diagnosis of ankle injuries [2,36-39], and management of ankle injuries [3,40-44], there were a total of 76 publications identified for further analysis. These were divided into two main categories: 16 qualitative studies [45-60] and 61 quantitative studies. These 60 studies were further grouped into 13 studies using goniometers to measure ankle joint ROM [12-13,61-71], 18 studies involving dynamometers to measure ankle strength (4 studies about handheld dynamometers [15,72-74] and 14 studies about isokinetic dynamometers [14,75-87]), and 29 studies with innovative ankle measurement techniques developed to measure various ankle parameters, including ankle ROM, strength, torque, and stiffness that may be used for real-time assessment of patient improvement [16-17,88-114].

Assessment techniques requiring specialist training were included in 16 qualitative studies. An additional 31 quantitative studies involving goniometers or dynamometers were also found that mainly measure either ROM or strength - both parameters easily measured by a robot. Additional studies that provide information about parameters that can potentially be implemented in robotassisted training were the main focus of this article and included 29 quantitative studies. A total of 465 subjects participated in these 29 quantitative studies, of which 19 studies were conducted on less than 20 participants (Table 1). These participants comprised both healthy volunteers and patients with diverse ankle injuries.

\section{DISCUSSION}

\section{Qualitative Ankle Assessment Techniques}

With a view to understanding the clinical functional scales and how an assessment of improvement is conducted (and to better understand the accuracy requirements for measurement by robot-assisted techniques), the following sections describe the qualitative measurement techniques.

\section{Scoring Systems}

The traditional method of describing ankle injuries was to group the assessment results: good, fair, and poor [115]. In recent years, more accurate scoring systems have been developed for ankle performance or function assessment. SooHoo et al. demonstrated that the FFI (a self-administered index consisting of 23 items) was a reasonable measure to monitor ankle status by examining its level of correlation to the Medical Outcomes Study Short Form-36 on 73 patients [50]. Karlsson and Peterson presented a scoring scale based on the subjective assessment of the patient's symptoms and level of function, and the evidence on 148 patients demonstrated that this system could be used to evaluate ankle function before and after treatment of ankle joint [45]. More sophisticated, Kaikkonen et al. proposed a performance test protocol and scoring scale for functional evaluation of ankle injuries based on both subjective patient feedback and clinical ankle examinations, including the measurement of ROM, laxity of ankle joint, and muscle strength [48]. This method showed excellent reproducibility and the total score correlated obviously with isokinetic ankle strength, subjective opinion of recovery, and subjective functional assessment on 148 patients. All these systems involve subjective assessment from either physiotherapists or patients.

Niki et al. proposed new scales with improved expressions for Japanese people based on the clinical rating 
JRRD, Volume 51, Number 4, 2014

Table 1.

Reviewed studies of quantitative ankle measurement techniques.

\begin{tabular}{|c|c|c|c|c|c|c|}
\hline Study & $\begin{array}{l}\text { Subjects } \\
\text { (n) }\end{array}$ & $\begin{array}{c}\text { Subject } \\
\text { Characteristics }\end{array}$ & $\begin{array}{l}\text { Subject } \\
\text { Age (yr) }\end{array}$ & Methods & Measures & Reliability \\
\hline $\begin{array}{l}\text { Schepers and } \\
\text { Veltink, } 2006 \\
{[101]}\end{array}$ & 1 & Healthy subject & Not stated & Instrumented shoes & Ankle moment & $\begin{array}{l}\text { RMS difference of GRF: } \\
19.1 \mathrm{~N} \text {; RMS difference for } \\
\text { CoP: } 17.9 \mathrm{~N}\end{array}$ \\
\hline
\end{tabular}

Schepers et al., 1 Healthy subject Not stated Instrumented shoes

2007 [104]

Not stated

Foot and ankle dynamics

RMS difference of GRF: $0.012 \pm 0.001 \mathrm{~N} / \mathrm{N} ; \mathrm{CoP}$ estimation RMS difference: $5.1 \pm 0.7 \mathrm{~mm}$; RMS difference of heel position estimates: $18 \pm 6 \mathrm{~mm}$; ankle moment RMS difference: $0.004 \pm 0.001 \mathrm{Nm} / \mathrm{N}$; RMS difference of estimated power: $0.02 \pm 0.005 \mathrm{~W} / \mathrm{N}$

\begin{tabular}{|c|c|c|c|c|c|c|}
\hline $\begin{array}{l}\text { Rouhani et al., } \\
2011 \text { [109] }\end{array}$ & 22 & $\begin{array}{l}12 \text { patients with } \\
\text { ankle osteoarthri- } \\
\text { tis, } 10 \text { healthy } \\
\text { subjects }\end{array}$ & $\begin{array}{l}\text { Patients: } 58 \pm \\
\text { 13; healthy sub- } \\
\text { jects: } 61 \pm 13\end{array}$ & $\begin{array}{l}\text { Ambulatory system con- } \\
\text { sisting of plantar pres- } \\
\text { sure insole and inertial } \\
\text { sensors }\end{array}$ & $\begin{array}{l}\text { Ankle force, moment, } \\
\text { and power }\end{array}$ & $\begin{array}{l}\text { High repeatability }(\mathrm{CMC}> \\
0.7)\end{array}$ \\
\hline $\begin{array}{l}\text { Keating et al., } \\
2000[93]\end{array}$ & 31 & $\begin{array}{l}10 \text { unimpaired } \\
\text { physiotherapy stu- } \\
\text { dents, } 21 \text { subjects } \\
\text { with stroke }\end{array}$ & $\begin{array}{l}\text { Impaired group: } \\
75.4 \pm 8.0 \text {; } \\
\text { healthy group: } \\
24.3 \pm 3.9\end{array}$ & Lidcombe Template & $\begin{array}{l}\text { Magnitude and direction } \\
\text { of force applied to dorsi- } \\
\text { flex foot }\end{array}$ & $\begin{array}{l}\text { Highly reliable for both } \\
\text { groups }(r>0.92)\end{array}$ \\
\hline $\begin{array}{l}\text { Moseley and } \\
\text { Adams, } 1991 \\
{[91]}\end{array}$ & 15 & $\begin{array}{l}5 \text { staff members, } \\
5 \text { people with CVA, } \\
5 \text { adults with head } \\
\text { injury }\end{array}$ & Not stated & Lidcombe Template & $\begin{array}{l}\text { Angle and force in ankle } \\
\text { dorsiflexion }\end{array}$ & $\begin{array}{l}\text { ICC for combined group } \\
\text { data: } 0.97 \text {; intertester } \\
\text { agreement: } 77 \%\end{array}$ \\
\hline $\begin{array}{l}\text { Wilken et al., } \\
2011 \text { [110] }\end{array}$ & 29 & $\begin{array}{l}\text { Validity testing: } \\
12 \text { participants }(6 \mathrm{M} \text {, } \\
6 \mathrm{~F} \text {; height: } 1.7 \pm \\
0.1 \mathrm{~m} \text {; body mass: } \\
72 \pm 12 \mathrm{~kg}) \text {; Inter- } \\
\text { tester reliability: } \\
17 \text { participants }(7 \mathrm{M} \text {, } \\
10 \mathrm{~F} \text {; height: } 1.7 \pm \\
0.1 \mathrm{~m} \text {; body mass: } \\
88 \pm 21 \mathrm{~kg})\end{array}$ & $\begin{array}{l}\text { Validity group: } \\
23 \pm 3 \text {; Inter- } \\
\text { tester reliability } \\
\text { group: } 52 \pm 15\end{array}$ & IAROM device & $\begin{array}{l}\text { Ankle dorsiflexion } \\
\text { motion and stiffness }\end{array}$ & $\begin{array}{l}\text { Validity testing ICC values: } \\
0.95-0.98 \text {; reliability test- } \\
\text { ing ICC values: } 0.90-0.95 \text {; } \\
\text { ICCs for ankle joint dorsi- } \\
\text { flexion stiffness: } 0.71 \text { (knee } \\
\text { in extended position) and } \\
0.85 \text { (knee in flexed } \\
\text { position) }\end{array}$ \\
\hline
\end{tabular}


Table 1. (cont)

Reviewed studies of quantitative ankle measurement techniques.

\begin{tabular}{|c|c|c|c|c|c|c|}
\hline Study & $\begin{array}{l}\text { Subjects } \\
\text { (n) }\end{array}$ & $\begin{array}{c}\text { Subject } \\
\text { Characteristics }\end{array}$ & $\begin{array}{l}\text { Subject } \\
\text { Age (yr) }\end{array}$ & Methods & Measures & Reliability \\
\hline $\begin{array}{l}\text { Peng et al., } \\
2011[108]\end{array}$ & 22 & $\begin{array}{l}12 \text { children with CP } \\
\text { with ankle spastic- } \\
\text { ity, } 5 \text { healthy chil- } \\
\text { dren, } 5 \text { healthy } \\
\text { adults }\end{array}$ & $\begin{array}{l}\text { Children with } \\
\text { CP: } 4-19 \text {; } \\
\text { healthy chil- } \\
\text { dren: } 12-14 \text {; } \\
\text { healthy adults: } \\
21-31\end{array}$ & MSE & $\begin{array}{l}\text { Ankle ROM, elastic } \\
\text { stiffness, and Tardieu R1 } \\
\text { catch angle at different } \\
\text { velocities }\end{array}$ & $\begin{array}{l}\text { High reproducibility with } \\
\text { ICC }=0.82 ; \text { Pearson } r= \\
0.81 ; p=0.002\end{array}$ \\
\hline $\begin{array}{l}\text { Kobayashi et } \\
\text { al., } 2010[16]\end{array}$ & 2 & Patients with stroke & 49 and 34 & $\begin{array}{l}\text { Manual ankle assess- } \\
\text { ment device }\end{array}$ & Ankle stiffness & Not stated \\
\hline $\begin{array}{l}\text { Kobayashi et } \\
\text { al., } 2011[107]\end{array}$ & 10 & $\begin{array}{l}\text { Subjects with hemi- } \\
\text { plegia (all M) }\end{array}$ & $54.3 \pm 8.4$ & $\begin{array}{l}\text { Manual ankle assess- } \\
\text { ment device }\end{array}$ & $\begin{array}{l}\text { Ankle stiffness and } \\
\text { ROM }\end{array}$ & $\begin{array}{l}\text { High reliability, with ICC } \\
\text { values }>0.97\end{array}$ \\
\hline $\begin{array}{l}\text { Sung et al., } \\
2010[106]\end{array}$ & 46 & $\begin{array}{l}\text { Sex-matched } \\
\text { healthy subjects }\end{array}$ & $\geq 20$ & $\begin{array}{l}\text { Intelligent stretching } \\
\text { device }\end{array}$ & Ankle stiffness & $\begin{array}{l}\text { Reliability ICC coefficient } \\
\text { of ankle stiffness between- } \\
\text { day for both examiners: } \\
0.77 \text { (SEM of } 0.05 \text { ) for } \\
\text { right ankle and } 0.76 \text { (SEM } \\
\text { of } 0.04 \text { ) for left ankle }\end{array}$ \\
\hline $\begin{array}{l}\text { Loram and } \\
\text { Lakie, } 2002 \\
{[94]}\end{array}$ & 15 & $\begin{array}{l}\text { Healthy subjects } \\
(8 \mathrm{M}, 7 \mathrm{~F})\end{array}$ & $20-68$ & $\begin{array}{l}\text { Ankle stiffness measur- } \\
\text { ing apparatus }\end{array}$ & Ankle stiffness & $\begin{array}{l}\text { Coefficient of variation: } \\
5 \%\end{array}$ \\
\hline $\begin{array}{l}\text { Casadio et al., } \\
2005[100]\end{array}$ & 18 & $\begin{array}{l}\text { Healthy subjects } \\
(9 \mathrm{M}, 9 \mathrm{~F})\end{array}$ & $21-31$ & $\begin{array}{l}\text { Force platform and } \\
\text { motorized footplate } \\
\text { apparatus }\end{array}$ & $\begin{array}{l}\text { Intrinsic ankle stiffness } \\
\text { during quiet standing }\end{array}$ & Not stated \\
\hline $\begin{array}{l}\text { Ji et al., } 2004 \\
{[98]}\end{array}$ & 4 & $\begin{array}{l}\text { Healthy subjects } \\
(2 \mathrm{M}, 2 \mathrm{~F})\end{array}$ & $29-70$ & $\begin{array}{l}\text { Computational method } \\
\text { with MATLAB }\end{array}$ & Ankle postural stiffness & $\begin{array}{l}\text { High coefficient values of } \\
\text { determination }\end{array}$ \\
\hline
\end{tabular}


JRRD, Volume 51, Number 4, 2014

Table 1. (cont)

Reviewed studies of quantitative ankle measurement techniques.

\begin{tabular}{ccccccc}
\hline \multicolumn{1}{c}{ Study } & $\begin{array}{c}\text { Subjects } \\
(\boldsymbol{n})\end{array}$ & $\begin{array}{c}\text { Subject } \\
\text { Characteristics }\end{array}$ & $\begin{array}{l}\text { Subject } \\
\text { Age }(\mathbf{y r})\end{array}$ & Methods & Measures & Reliability \\
\hline $\begin{array}{l}\text { Mirbagheri et } \\
\text { al., 1996 [17] }\end{array}$ & 11 & $8 \mathrm{M}, 3 \mathrm{~F}$ & Not stated & $\begin{array}{l}\text { Parallel-cascade system } \\
\text { identification method }\end{array}$ & $\begin{array}{l}\text { Ankle dynamic stiffness } \\
\text { and separation of intrinsic } \\
\text { and reflex components intrasubject reliabil- }\end{array}$ & $\begin{array}{l}\text { ity }(r>0.8) \text { but high inter- } \\
\text { subject variability }\end{array}$
\end{tabular}

$\begin{array}{lllll}\begin{array}{l}\text { Forster, 2003 } \\ {[95]}\end{array} & 1 & \text { Normal subject } & \text { Not stated } & \begin{array}{l}\text { Bilateral electro-hydraulic } \\ \text { actuator system }\end{array}\end{array}$

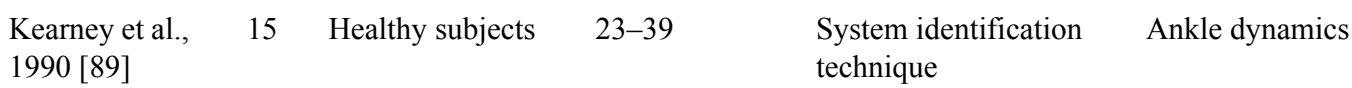

Weiss et al., 1990 [90]

Chesworth and Vandervoort, 1988 [88]

Nordquist and

Hull, 2007

[102]

\section{Healthy subjects $\quad 26-46$} (all F) boarder (height: $185 \mathrm{~cm}$; weight: $74.8 \mathrm{~kg})$

Fong et al., 2012 [111]

Winegard et al., 1998 [92]

Naito et al., 2012 [114] from fractures of lower leg (2 M, $1 \mathrm{~F})$ mens, 6 subjects

(all F; height: $1.60 \pm$

$0.04 \mathrm{~m}$; body mass:

$54.8 \pm 5.8 \mathrm{~kg}$ )

$105 \mathrm{M}, 5 \mathrm{~F}$

$73-92$

$4 \quad$ Healthy subjects

(all M; height:

$170.3 \pm 5.2 \mathrm{~cm}$; weight: $61.5 \pm$ $15.4 \mathrm{~kg}$ )$$
\text { pronation torque }
$$

System identification technique

Ankle torque measurement system

"Elbow-type" ISL

Dynamic ankle motion in field environment

Passive ankle mechanical stiffness

Ankle dynamics

Ankle supination and pronation torque

Footplate apparatus

Intrasubject reliability was as good as or better than most clinical measures, and intersubject variability was somewhat larger

Ankle dynamics measures were qualitatively similar to those of normals: stiffness was low in region near midrange and increased obviously near limits of movement

High reproducibility

Mechanical jig

Voluntary isometric

Mean reliability coefficient strength and evoked iso- of all measurements on the metric twitch properties, dorsiflexion and plantar $\mathrm{M}$-wave amplitude, and passive tension

flexor muscle groups was $0.91 \pm 0.05$

\footnotetext{
Estimation of muscle Passive ankle joint Predicted data are consislength parameters based moment vs ankle angle; tent with measured data on measurement data ankle muscle length
} 
Table 1. (cont)

Reviewed studies of quantitative ankle measurement techniques.

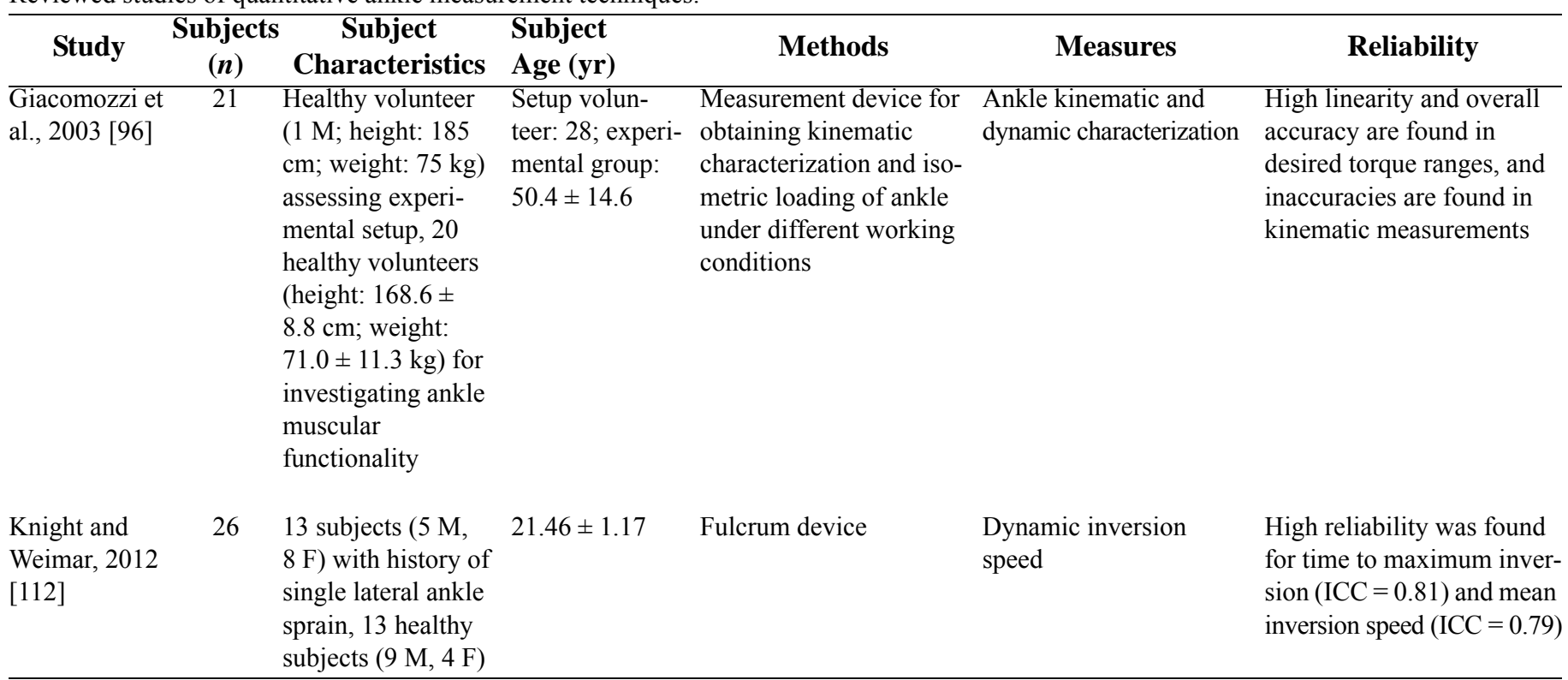

$\mathrm{CMC}=$ coefficient of multiple correlations, $\mathrm{CoP}=$ center of pressure, $\mathrm{CP}=$ cerebral palsy, $\mathrm{CVA}=$ cerebral vascular accident, $\mathrm{F}=$ female, $\mathrm{GRF}=$ ground reaction force, IAROM = Iowa Ankle ROM, ICC = intraclass correlation coefficient, ISL $=$ instrumented spatial linkage, $\mathrm{M}=\mathrm{male}, \mathrm{ML}=$ medial/lateral, $\mathrm{MS}=$ multiple sclerosis, MSE = manual spasticity evaluator, RMS = root-mean-square, $\mathrm{ROM}=$ range of motion, $\mathrm{SCI}=$ spinal cord injury, SEM = standard error of measurement.

systems established by the American Orthopedic Foot and Ankle Society and the Japanese Orthopedic Association's foot rating scale (JOA scale) [54]. Reliability analysis on 65 clinicians and 610 patients was further conducted by Niki et al. [55], and the results showed that this newly established standard rating scale and the JOA scale are highly reliable, to some extent, which demonstrated its population-specific characteristic.

In contrast, two studies did not show positive effects for a certain group of people. Ansari et al. found that reliability of the Modified Tardieu Scale in the assessment of poststroke ankle plantar flexor spasticity was not high [46], and Campanini et al. demonstrated that the treatment of ankle spasticity for patients with cerebral vascular accident could not rely on the Ashworth score completely [47].

Other studies investigated and compared various qualitative ankle assessment systems. Haywood et al. summarized seven disease-specific assessment methods of ankle performance (Ankle Joint Functional Assessment Tool, Clinical Trauma Severity Score, Composite Inversion Injury Scale, Kaikkonen Functional Scale, Karlsson Ankle Function Score, Olerud and Molander Ankle Score, and the Point System) and concluded that any measure should be used with caution until appropriate evidence is provided [49]. However, further investi- gation into the effectiveness of functional outcome scores specific to patients was necessary, which was also supported by Farrugia et al. [53].

\section{Foot and Ankle Disability Index and Foot and Ankle Ability Measure}

Although the FADI and Foot and Ankle Ability Measure (FAAM) belong to the category of scoring systems, they were discussed independently since a systematic review [56] identified them as the most appropriate outcome instruments to quantify functional limitations in patients with chronic ankle instability (CAI).

Hale and Hertel advocated the use of the FADI and FADI Sport self-report instruments in clinical care and research applications in young adults with CAI [57], and these instruments appeared to be reliable in assessing functional limitations. Further, Wikstrom et al. concluded that self-assessed disability got from these systems was greater in subjects with CAI than uninjured groups, which showed their patient-specific characteristic [60]. More advanced, the FAAM (as the later version of the FADI) showed satisfactory validity and reliability on groups with various ankle injuries [51]. Martin et al. developed the FAAM for measuring region-specific and non-disease-specific function of the foot and ankle and 
concluded that it was a reliable and valid measure of physical function for individuals with a wide array of musculoskeletal foot and ankle disorders [58]. Further, Carcia et al. concluded that the FAAM may be used to detect self-reported functional deficits related to CAI [59], and Cosby and Hertel verified its reliability and validity on a male basketball player with inversion ankle sprain [52]. As for the region-specific attribute, direct comparison among different populations is quite necessary, although some versions have proved to be reliable. For example, Mazaheri et al. conducted tests on 93 Persian patients and found that the FAAM was a reliable and valid measure to quantify physical function [51]. Therefore, it can be summarized that the FADI and FAAM are usually reliable, but larger sample sizes with a greater diversity of populations and various ankle injuries should be investigated in future research.

Taking all studies into consideration, it can be concluded that these scoring systems are usually regionspecific and disease-specific; thus, a universally designed method with convincing validity and reliability is essential. Further, these currently available systems usually require participants to conduct a series of functional activities and answer subjective questionnaires and then rate function on a prespecified scale based on ankle performance. This assessment, which usually lasts a few minutes or longer, makes it difficult for the realization of real-time evaluation when used in robot-assisted therapy, though some of the techniques and questions may be valuable in engaging the user in understanding the therapy being undertaken, especially during a robot-assisted program.

\section{Quantitative Ankle Assessment Techniques}

To better be able to quantify functional improvement using robot-assisted therapy, quantitative measures are required. These should incorporate all aspects of ankle control, including ankle kinematics and kinetics such as ROM, muscle strength, and joint stiffness. This section discusses the tools (standard techniques and innovative techniques) to measure these aspects of functional control.

\section{Standard Techniques}

Ankle range of motion. The ankle ROM is an important functional parameter that relates to the efficiency of gait. An effective measurement of ankle ROM in all three planes is important to better understand functional improvement. For this reason, ankle ROM is frequently assessed clinically. This section discusses devices that can be used for determining ankle ROM and provides important information about requirements in the development of an assessment method implementable with a robot to assist ankle therapy.

Goniometers have been considered as the standard method of ankle ROM measurement with a satisfactory reliability, especially for ankle dorsiflexion [12-13,61$66,68-71]$. One study showed its poor interrater reliability in ankle joint dorsiflexion [67], and measures using goniometry have been shown to be tester dependent [110]. However, Wilken et al. reported that the validity and repeatability can be problematic due to goniometer alignment, as well as potential variations in location and magnitude of forces applied to the foot [97]. To address these limitations, the Iowa Ankle ROM (IAROM) device allows angular measurements at predetermined force levels using a digital inclinometer and a handheld force gauge to measure ankle dorsiflexion ROM in a clinically friendly and cost-effective way $[97,110]$. The clinical test on 29 participants proved its repeatability and validity, but the application combined with robot-assisted therapy is restricted due to the manual operation of a handheld force gauge.

Ankle strength. Ankle strength is the amount of force ankle muscles can generate. The ability to generate force is necessary for all types of movement.

A hand dynamometer is usually used to measure grip and pinch strength and to perform muscle fatigue studies. Some studies have demonstrated that handheld dynamometers can be reliably used for measurement of ankle strength [15,72-74]. Different from the normal application, there is an innovative handheld dynamometer using a torque wrench and a goniometer that can measure static ankle angle and moment reliably and precisely [74]. Unfortunately, for the same reasons as the IAROM device, the manual operation of handheld dynamometer impedes its adoption when combined with robot-assisted therapy.

The isokinetic dynamometer is widely used during the various phases of rehabilitation. It is a precisionbased electrical instrument that measures the performance of various muscle groups in the body. Isokinetic dynamometers including the Biodex dynamometer, the Cybex Norm, and the Kin Com II dynamometer in some studies have been demonstrated as the gold standard for measurement of ankle strength [14,75-79,81-87]. One study, however, showed that the validity of ankle inversion and eversion torque measurement using a manufactured 
prototype ankle inversion and eversion attachment device on the Kin Com II dynamometer was questionable [80]. In addition, there are two studies $[79,86]$ that assessed passive ankle stiffness with the isokinetic dynamometer by calculation [86] that presented satisfactory validity and reliability by clinical tests on 15 subjects. Although isokinetic dynamometers can be used for measuring ankle ROM, strength, and even stiffness, the main limitation is that ankle measurement and assessment is usually available only in the sagittal plane.

\section{Innovative Techniques}

Ankle torque and stiffness. Ankle stiffness is an important mechanical parameter that indicates the moment required for rotation and the resistance to an external perturbation [116-117]. Devices and techniques specifically to assess ankle stiffness have been developed. The working principles of most of these systems are similar. The system normally includes an actuator to generate rotation torque, a potentiometer to measure the angular displacement, and torque sensors to measure ankle moment. During tests, patients are usually required to move their ankles with different speeds, and the ankle stiffness will be calculated as the derivative of torque over angular displacement. Several of these systems have been evaluated in clinical settings, and the results showed that these types of devices can be a useful tool in the clinical assessment of ankle stiffness.

The Lidcombe template consisting of a spring balance and a perspex sheet ruled with parallel lines was adopted in Moseley and Adams and Keating et al. to measure the angle and force in ankle dorsiflexion, showing high reliability between testers [91,93]. Lorentzen et al. investigated the accuracy and reliability of a portable Neurokinetics RA1 Ridgidity analyzer used for measuring ankle stiffness on 83 participants [113]. Results showed that it could potentially be a useful diagnostic tool for measuring ankle stiffness, although it was originally developed to test elbow rigidity. These devices require manual operation from physiotherapists; thus, their applications when combined with robot-assisted therapy are restricted.

Direct ankle assessment techniques using the potentiometer and torquemeter are easier to apply during robotassisted therapy. Two studies constructed a manual device to measure ankle joint ROM and stiffness in patients with stroke and showed promise for clinical application [16,107], of which Kobayashi et al. [107] pre- sented an improved design based on the device in Saleh and Murdoch [24]. The manual spasticity evaluator (MSE) was used for the quantitative evaluation of ankle spasticity and stiffness in two studies that conducted clinical trials on six children with cerebral palsy, five typically developed children, and five typically developed adults $[99,108]$. The results showed that ankle spasticity assessment could be more accurately performed using MSE. These two devices also need manual drive when measuring ankle stiffness, but this limitation can be easily overcome using a motor or other actuators.

Ankle stiffness can also be determined by measuring torque and joint angles in a more sophisticated way. A bilateral electro-hydraulic actuator system with position and torque transducers was used in Forster to measure dynamic ankle joint stiffness during upright human stance [95]. Sung et al. used an intelligent stretching device for ankle stiffness measurement [106]. They applied system identification techniques to characterize dynamic joint properties, including joint stiffness, viscous damping, and foot inertia properties during smallamplitude perturbations. Forty-six sex-matched healthy subjects participated in the trial, and results showed that this method was reproducible and consistent in ankle dorsiflexion and plantar flexion measurements. Chesworth and Vandervoort demonstrated that the proposed ankle torque measurement unit consisting of a potentiometer and a strain gauge could be a useful tool in the clinical assessment of passive ankle stiffness [88].

Different from single-plane assessment, Giacomozzi et al. developed a device for ankle kinematic and kinetics characteristics in three planes [96]. This device measured the three-dimensional (3D) movement of the foot with respect to the shank and evaluated torques around the three articular axes based on the measured position and moment information from transducers. Some studies also focus on ankle stiffness in quiet standing or postural control. Loram and Lackie used an inverted pendulum with a position transducer and a torque cell to measure ankle stiffness in quiet standing [94]. Casadio et al. used a device consisting of a motorized footplate mounted on a force platform for the direct of intrinsic ankle stiffness in quiet standing [100]. Ji et al. proposed a computational method to evaluate postural stiffness through ground reaction forces [98].

From a biomechanical perspective, quantitative assessment of ankle muscles and ligaments based on measured joint kinematics and kinetics is also necessary. 
Ankle stiffness is mainly determined by grouping all muscles and ligaments surrounding the joint in which the passive component is the result of their viscoelastic properties [118]. Unfortunately, there have only been a few studies in which the muscular-skeletal properties of the ankle complex are considered. Naito et al. [114] applied a musculo-skeletal structure with a Hill-type muscle model for calculating individual muscle length based on the data from the device used in Kobayashi et al., and the results from four healthy subjects suggested its success [16,107]. A kinematics-based ankle model with major muscles and ligaments can be a promising approach to study passive ankle torque or stiffness, and comparisons with traditional methods in terms of accuracy should be conducted.

These ankle stiffness measurement methods applied different measuring techniques and thus the applicable scopes varied. The majority of these studies were able to assess ankle stiffness only in the sagittal plane, while a unique medial/lateral swaying cradle device in Zinder et al. was developed to measure inversion and eversion ankle stiffness with a satisfactory validity and reliability [105]. More directly related to robot-assisted therapy, the anklebot showed its potential to estimate ankle stiffness in three planes, although only tests in dorsiflexion and plantar flexion have been conducted [103]. Another two limitations of these studies are the small sample sizes and the lack of reaction forces acting on the device.

In summary, ankle stiffness assessment techniques mainly consist of direct measurement using the potentiometer and torquemeter based method (PT-BM) and an inverse dynamics based method (ID-BM) to determine the kinematics using reaction forces as the inputs. Some studies used the handheld dynamometer to estimate ankle stiffness $[74,86]$. Table 2 is presented to analyze their prospects when used in robot-assisted therapy. The hand- held dynamometer based method is subject to manual operation, to some extent, which affects the measurement accuracy. PT-BM cannot be used in parallel robots due to the use of the torquemeter that is usually installed between the power producer and the load. In other words, three potentiometers as well as three torquemeters for 3D ankle assessment are required. By contrast, the ID-BM is promising when combined with robot-assisted therapy. 3D ankle assessment using a 6-axis load cell will be available, but the validity and reliability need to be analyzed prior to use.

Other ankle kinematics and kinetics. Although ankle ROM, strength, torque, or stiffness have been measured quantitatively based on various devices and techniques, there are still some devices developed that can measure certain parameters not common in clinical application. For example, Knight and Weimar developed a fulcrum device to measure dynamic inversion speed, and the data from 26 participants showed high reliability for assessing maximum inversion and mean inversion speed [112].

In addition to these devices commonly used in the laboratory setting, three studies $[101,104,109]$ developed ambulatory measurement systems of foot and ankle kinematics and kinetics in the sagittal plane, of which two studies $[101,104]$ assessed instrumented shoes on healthy subjects. Results showed good correspondence between the proposed system and the reference, and another study also showed good reliability but with a different ambulatory ankle kinetics measurement system on 12 patients and 10 healthy subjects [109]. Additionally, a new instrumented spatial linkage was used in Norquist and Hull to measure dynamic ankle joint motion, and data from an experienced snowboarder demonstrated its utility in a field environment [102]. These ambulatory measuring techniques showed their potential in certain activities.

Table 2.

Prospect analysis of handheld dynamometer based method (HD-BM), potentiometer and torquemeter based method (PT-BM), and inverse dynamics based method (ID-BM) when used in robot-assisted therapy.

\begin{tabular}{lllc}
\hline Method & \multicolumn{1}{c}{ Advantages } & \multicolumn{1}{c}{ Disadvantages } & \multicolumn{1}{c}{$\begin{array}{c}\text { Prospect in } \\
\text { Robot-Assisted Therapy }\end{array}$} \\
\hline HD-BM & Simple & Manual operation & Poor \\
PT-BM & Reliable & $\begin{array}{c}\text { Restricted by robot structure } \\
\text { and usually only measures in } \\
\text { single plane }\end{array}$ & Reasonable \\
& & Validity and reliability of 3D & Good \\
ID-BM & 3D ankle assessment & & ankle assessment are not clear \\
\hline
\end{tabular}


Identification methods are commonly used to estimate ankle mechanics (passive and active stiffness) based on measured information. Kearney et al. used a system identification method to estimate ankle mechanics based on measured information from a potentiometer and a torquemeter [89]. Tests on 15 young adults showed that it had a good intrasubject variability and a somewhat larger intersubject variability. Mirbagheri et al. [17] described a parallel-cascade system identification method that had similar variability with Kearney et al. [89] when used to determine the intrinsic and reflex contributions to dynamic ankle stiffness. Further, Weiss et al. tried to monitor the mechanical consequences of soft tissue injury based on joint dynamics, and tests on three patients demonstrated its promise in clinical application [90].

To summarize, while Rome concluded that ankle joint dorsiflexion assessment was controversial in terms of measurement accuracies due to different study designs [119], most quantitative ankle measuring techniques have proved to be reliable for a certain individual or group. However, they were usually available for only ankle dorsiflexion and plantar flexion under passive motion in terms of kinematics and kinetics. Studies involving direct comparison in terms of reliability and validity among different devices and techniques are also lacking. Studies with less than 10 participants should be further validated with a larger sample size in the future.

\section{Ideal Measurement Device for Use with Robot-Assisted Therapy}

An ideal system to evaluate functional improvement using robotic assessment would include 3D assessment in terms of kinematics and kinetics.

In general, goniometers and dynamometers have been used commercially and can be considered standard tools for measuring ankle joint ROM and muscle strength but are not used to measure other attributes of functional improvement after ankle injury. Both ROM and strength can readily be measured using robotic techniques. Dynamometers and goniometers should be used as the gold standard with which to compare when testing reliability and reproducibility of robot measurement techniques. For torque or stiffness measurements, a combination of a 6axis load cell and a parallel robot shows great potential for 3D ankle assessment during robot-assisted therapy. Further, a kinematics-based ankle model with major muscles and ligaments looks promising when used to study the passive components. A combination of $3 \mathrm{D}$ measure- ment and the model-based method allows for differentiation between the active and passive components.

Kinematic and kinetic parameters of measurement are diverse, with no consensus as to device, technique, clinician expertise, or even whether to test passive or active motion. Studies involving direct comparison in terms of reliability and validity among different devices and techniques are important to better understand how these can predict function in the future. Further research should also focus on analyzing real-time ankle muscle and ligaments parameters in all three planes based on measured ankle kinematics and kinetics information. A robot assessment technique can be developed that is consistent in all aspects of kinematic and kinetic measurement, allowing for consistency for both before and after intervention and additionally among different patients.

\section{Limitations of Robot Assessment}

Robots are actuated manually or through the use of motors, linear actuators, and/or rotary actuators, which influence measuring accuracy. One study shows that difficulty existed in controlling the velocity applied to the ankle and the applied force during manual assessments, especially during high velocity or high ankle resistance conditions [120]. Comparisons among other actuators are lacking. Another study suggests that accurate movement control can lead to more reliable measurement outcomes [16]. Therefore, an accurate motion control system is necessary for developing a reliable and repeatable ankle assessment device.

\section{Limitations of Search Strategy}

An attempt was made to include all studies related to ankle measuring techniques. It is assumed that these selected studies used different participants. Other publications may exist where "foot," "lower extremity," or "lower limb" are identified as a key term instead of ankle. However, these may lead to potential incomplete searches, as well as some constraints like publication dates and languages.

\section{CONCLUSIONS}

While most qualitative ankle assessment systems have been shown to be reliable, they are usually regionspecific and disease-specific; thus, a universally designed method with convincing validity and reliability is essential. 
Further, the assessment items usually involve functional ankle tests, questionnaire answers, and clinical ankle examination, which make the generation of immediate evaluation results (real-time monitoring from a robotic perspective) difficult.

Most quantitative ankle assessment techniques are reliable in measuring ankle kinematics and kinetics but are usually only available for the sagittal plane. Limited studies determine kinematics and kinetics in all three planes, where motions of the ankle joint and the subtalar joint actually occur [5]. Once these kinematics and kinetics are better understood, online modeling may allow for alteration of interventions or control strategies during robot-assisted therapy based on real-time ankle characteristics. In addition, these innovative ankle assessment devices were usually evaluated with no more than 30 participants and should be further validated with a larger sample size. Direct comparison among different devices and techniques for a specific ankle parameter should also be conducted to determine what could be the ideal effective ankle assessment tools in a clinical environment.

\section{ACKNOWLEDGMENTS}

\author{
Author Contributions: \\ Study concept and design: M. Zhang. \\ Acquisition of data: M. Zhang. \\ Analysis and interpretation of data: M. Zhang, T. C. Davies, \\ Y. Zhang, S. Xie. \\ Drafting of manuscript: M. Zhang. \\ Critical revision of manuscript for important intellectual content: \\ T. C. Davies, Y. Zhang, S. Xie. \\ Final approval for manuscript to be published: M. Zhang, \\ T. C. Davies, Y. Zhang, S. Xie.
}

Financial Disclosures: The authors have declared that no competing interests exist.

Funding/Support: This material was based on work supported by the University of Auckland Faculty of Engineering Research Development Fund (grant 3625057, Physical Robot-Human Interaction for Performance-Based Progressive Robot-Assisted Therapy) and the China Sponsorship Council.

Additional Contributions: The authors would like to express their sincere thanks to Emil Melnichenko in references search. Further, the authors thank Anoop Nandakumar for grammatical corrections, as well as Wenhui Zhu, Ran Tao, and Ye Ma for their suggestions about data extraction and analysis.

\section{REFERENCES}

1. Segal D, Wiss DA, Whitelaw GP. Functional bracing and rehabilitation of ankle fractures. Clin Orthop Relat Res. 1985;(199):39-45. [PMID:3930123]

2. Riley GM. Magnetic resonance imaging in the evaluation of sports injuries of the foot and ankle: A pictorial essay. J Am Podiatr Med Assoc. 2007;97(1):59-67. [PMID:17218626] http://dx.doi.org/10.7547/0970059

3. Mai N, Cooper L. Assessment of ankle injuries. J Sch Nurs. 2009;25(1):34-39. [PMID:19197016] http://dx.doi.org/10.1177/1059840508327629

4. Slimmon D, Brukner P. Sports ankle injuries - assessment and management. Aust Fam Physician. 2010;39(1-2):1822.[PMID:20369129]

5. Sammarco GJ. Rehabilitation of the foot and ankle. St. Louis (MO): Mosby; 1995.

6. Accident Compensation Corporation. ACC 898 Managing soft tissue ankle injuries: A summary of recent research [Internet]. Auckland (New Zealand): Accident Compensation Corporation; 2014. Available from:

http://www.acc.co.nz/search-results/index.htm?ssUserText $=$ ankle + cost

7. Waterman BR, Owens BD, Davey S, Zacchilli MA, Belmont PJ Jr. The epidemiology of ankle sprains in the United States. J Bone Joint Surg Am. 2010;92(13):2279-84. [PMID:20926721] http://dx.doi.org/10.2106/JBJS.I.01537

8. Barnes MP, Good DC. Neurological rehabilitation. Edinburgh (United Kingdom): Elsevier; 2013.

9. Zhang LQ, Chung SG, Bai Z, Xu D, van Rey EM, Rogers MW, Johnson ME, Roth EJ. Intelligent stretching of ankle joints with contracture/spasticity. IEEE Trans Neural Syst Rehabil Eng. 2002;10(3):149-57. [PMID:12503779] http://dx.doi.org/10.1109/TNSRE.2002.802857

10. Bauer M, Bergström B, Hemborg A, Sandegård J. Malleolar fractures: Nonoperative versus operative treatment. A controlled study. Clin Orthop Relat Res. 1985;(199):17-27. [PMID:3930121]

11. Mooney V, Stills M. Continuous passive motion with joint fractures and infections. Orthop Clin North Am. 1987; 18(1):1-9. [PMID:3796954]

12. Popoff M, Jourdan C, Dongas A, Schnitzler A. Reliability of goniometric measurement of ankle dorsiflexion in hemiparetic patients. Ann Phys Rehabil Med. 2012; 55:e28 http://dx.doi.org/10.1016/j.rehab.2012.07.073

13. Watkins B, Darrah J, Pain K. Reliability of passive ankle dorsiflexion measurements in children: Comparison of universal and biplane goniometers. Pediatr Phys Ther. 1995;7(1):3-8. 
14. Holmbäck AM, Porter MM, Downham D, Lexell J. Reliability of isokinetic ankle dorsiflexor strength measurements in healthy young men and women. Scand J Rehabil Med. 1999;31(4):229-39. [PMID:10599900]

15. Spink MJ, Fotoohabadi MR, Menz HB. Foot and ankle strength assessment using hand-held dynamometry: Reliability and age-related differences. Gerontology. 2010; 56(6): 525-32. [PMID:19955706] http://dx.doi.org/10.1159/000264655

16. Kobayashi T, Leung AK, Akazawa Y, Tanaka M, Hutchins SW. Quantitative measurement of spastic ankle joint stiffness using a manual device: A preliminary study. J Biomech. 2010;43(9):1831-34. [PMID:20189176] http://dx.doi.org/10.1016/j.jbiomech.2010.02.024

17. Mirbagheri MM, Kearney RE, Barbeau H. Quantitative, objective measurement of ankle dynamic stiffness: Intrasubject reliability and intersubject variability. Proceedings of the 18th Annual International Conference of the IEEE Engineering in Medicine and Biology Society; 1996 Oct 31-Nov 3; Amsterdam, the Netherlands. p. 585-86.

18. Tsoi YH, Xie SQ, Graham AE. Design, modeling and control of an ankle rehabilitation robot. Stud Comput Intell. 2009;177:377-99. http://dx.doi.org/10.1007/978-3-540-89933-4_18

19. Waldman G, Wu YN, Ren Y, Li Y, Guo X, Roth EJ, Wang L, Zhang L. Stroke rehabilitation using a portable robot improves biomechanical and clinical outcome measures. Stroke. 2011;42(3):E128.

20. Satici AC, Erdogan A, Patoglu V. Design of a reconfigurable ankle rehabilitation robot and its use for the estimation of the ankle impedance. Proceedings of the 2009 IEEE International Conference on Rehabilitation Robotics; 2009 Jun 23-26; Kyoto, Japan. p. 257-64.

21. Yoon J, Ryu J, Lim KB. Reconfigurable ankle rehabilitation robot for various exercises. J Robot Syst. 2006; 22(Suppl 1):S15-33.

22. Jamwal PK, Xie SQ, Hussain S, Parsons JG. An adaptive wearable parallel robot for the treatment of ankle Injuries. IEEE Trans Mech. 2012;19(1):64-75. http://dx.doi.org/10.1109/TMECH.2012.2219065

23. Xie SQ, Jamwal PK. An iterative fuzzy controller for pneumatic muscle driven rehabilitation robot. Expert Syst Appl. 2011;38(7):8128-37.

http://dx.doi.org/10.1016/j.eswa.2010.12.154

24. Saleh M, Murdoch G. In defence of gait analysis. Observation and measurement in gait assessment. J Bone Joint Surg Br. 1985;67(2):237-41. [PMID:3980533]

25. Oae K, Takao M, Uchio Y, Ochi M. Evaluation of anterior talofibular ligament injury with stress radiography, ultrasonography and MR imaging. Skeletal Radiol. 2010; 39(1): 41-47. [PMID:19685050] http://dx.doi.org/10.1007/s00256-009-0767-x
26. Brasseur JL, Luzzati A, Lazennec JY, Guérin-Surville H, Roger B, Grenier P. Ultrasono-anatomy of the ankle ligaments. Surg Radiol Anat. 1994;16(1):87-91.

[PMID:8047974]

http://dx.doi.org/10.1007/BF01627927

27. Zhang M, Davies TC, Xie S. Effectiveness of robotassisted therapy on ankle rehabilitation - a systematic review. J Neuroeng Rehabil. 2013;10:30.

[PMID:23517734]

http://dx.doi.org/10.1186/1743-0003-10-30

28. Kawakami K, Omori G, Terashima S, Sakamoto M, Hara T. Dynamic evaluation of the contact characteristics and three-dimensional motion for the ankle joint with lateral ligament injuries. JSME Int J Ser C Mech Syst Mach Elem Manuf. 2001;44(4):1082-88. http://dx.doi.org/10.1299/jsmec.44.1082

29. Siegler S, Wang D, Plasha E, Berman AT. Technique for in vivo measurement of the three-dimensional kinematics and laxity characteristics of the ankle joint complex. J Orthop Res. 1994;12(3):421-31. [PMID:8207596]

http://dx.doi.org/10.1002/jor.1100120315

30. Arndt A, Westblad P, Winson I, Hashimoto T, Lundberg A. Ankle and subtalar kinematics measured with intracortical pins during the stance phase of walking. Foot Ankle Int. 2004;25(5):357-64. [PMID:15134619]

31. Drost MR, Heemskerk AM, Strijkers GJ, Dekkers EC, van Kranenburg G, Nicolay K. An MR-compatible device for the in situ assessment of isometric contractile performance of mouse hind-limb ankle flexors. Pflugers Archiv. 2003; 447(3):371-75. [PMID:14530976] http://dx.doi.org/10.1007/s00424-003-1181-1

32. de Ruiter GC, Spinner RJ, Alaid AO, Koch AJ, Wang H, Malessy MJ, Currier BL, Yaszemski MJ, Kaufman KR, Windebank AJ. Two-dimensional digital video ankle motion analysis for assessment of function in the rat sciatic nerve model. J Peripher Nerv Syst. 2007;12(3):216-22. [PMID:17868249] http://dx.doi.org/10.1111/j.1529-8027.2007.00142.x

33. Newton JM, Dong Y, Hidler J, Plummer-D'Amato P, Marehbian J, Albistegui-Dubois RM, Woods RP, Dobkin $\mathrm{BH}$. Reliable assessment of lower limb motor representations with fMRI: Use of a novel MR compatible device for real-time monitoring of ankle, knee and hip torques. Neuroimage. 2008;43(1):136-46. [PMID:18675363] http://dx.doi.org/10.1016/j.neuroimage.2008.07.001

34. de Vries JS, Kerkhoffs GM, Blankevoort L, van Dijk CN. Clinical evaluation of a dynamic test for lateral ankle ligament laxity. Knee Surg Sports Traumatol Arthrosc. 2010;18(5):628-33. [PMID:19924401] http://dx.doi.org/10.1007/s00167-009-0978-7

35. LaPointe SJ, Siegler S, Berman AT, Arlosoroff C. An instrumented linkage for the measurement of the rotatory 
stability of the human ankle complex. J Biomech. 1994; 27(6):807. http://dx.doi.org/10.1016/0021-9290(94)91349-8

36. Frater C, Van Der Wall H. Sport, scintigraphy and positioning of the foot and ankle in the assessment of musculoskeletal pathology: part II: common skeletal injuries. ANZ Nucl Med. 2007;38(2):14-19.

37. Farley FA, Kuhns L, Jacobson JA, DiPietro M. Ultrasound examination of ankle injuries in children. J Pediatr Orthop. 2001;21(5):604-7. [PMID:11521027] http://dx.doi.org/10.1097/01241398-200109000-00010

38. Hermans JJ, Wentink N, Beumer A, Hop WC, Heijboer MP, Moonen AF, Ginai AZ. Correlation between radiological assessment of acute ankle fractures and syndesmotic injury on MRI. Skeletal Radiol. 2012;41(7):787-801. [PMID:22012479] http://dx.doi.org/10.1007/s00256-011-1284-2

39. Tsui KB, Kong LC, Tsang LC. Ottawa ankle rules for assessment of ankle injuries. Hong Kong Pract. 2011; 33(1): 22-28.

40. Mei-Dan O, Kots E, Barchilon V, Massarwe S, Nyska M, Mann G. A dynamic ultrasound examination for the diagnosis of ankle syndesmotic injury in professional athletes: A preliminary study. Am J Sports Med. 2009;37(5):100916. [PMID:19336613] http://dx.doi.org/10.1177/0363546508331202

41. Porter DA. Evaluation and treatment of ankle syndesmosis injuries. Instr Course Lect. 2009;58:575-81. [PMID:19385568]

42. Weber M, Burmeister H, Flueckiger G, Krause FG. The use of weightbearing radiographs to assess the stability of supination-external rotation fractures of the ankle. Arch Orthop Trauma Surg. 2010;130(5):693-98. [PMID:20082083] http://dx.doi.org/10.1007/s00402-010-1051-1

43. Aloi M, Palma A, Davenport M, Kimes D. The use of emergency department ultrasound to evaluate ankle inversion injuries. Acad Emerg Med. 2011;18(Suppl 1):S172.

44. Mulligan EP. Evaluation and management of ankle syndesmosis injuries. Phys Ther Sport. 2011;12(2):57-69. [PMID:21496767] http://dx.doi.org/10.1016/j.ptsp.2011.03.001

45. Karlsson J, Peterson L. Evaluation of ankle joint function: The use of a scoring scale. Foot. 1991;1(1):15-19. http://dx.doi.org/10.1016/0958-2592(91)90006-W

46. Ansari NN, Naghdi S, Hasson S, Rastgoo M, Amini M, Forogh B. Inter- and intrarater reliability of the modified Tardieu Scale in the assessment of poststroke ankle plantarflexor spasticity. Brain Inj. 2012;26(4-5):543.

47. Campanini I, Merlo A, Cavazzuti L. What's the risk of using the Modified Ashworth Scale (MAS) to assess spasticity at the ankle? Gait Posture. 2011;33:S18-19. http://dx.doi.org/10.1016/j.gaitpost.2010.10.024
48. Kaikkonen A, Kannus P, Järvinen M. A performance test protocol and scoring scale for the evaluation of ankle injuries. Am J Sports Med. 1994;22(4):462-69.

[PMID:7943510] http://dx.doi.org/10.1177/036354659402200405

49. Haywood KL, Hargreaves J, Lamb SE. Multi-item outcome measures for lateral ligament injury of the ankle: A structured review. J Eval Clin Pract. 2004;10(2):339-52. [PMID:15189400] http://dx.doi.org/10.1111/j.1365-2753.2003.00435.x

50. SooHoo NF, Samimi DB, Vyas RM, Botzler T. Evaluation of the validity of the Foot Function Index in measuring outcomes in patients with foot and ankle disorders. Foot Ankle Int. 2006;27(1):38-42. [PMID:16442027]

51. Mazaheri M, Salavati M, Negahban H, Sohani SM, Taghizadeh F, Feizi A, Karimi A, Parnianpour M. Reliability and validity of the Persian version of Foot and Ankle Ability Measure (FAAM) to measure functional limitations in patients with foot and ankle disorders. Osteoarthritis Cartilage. 2010;18(6):755-59. [PMID:20338253] http://dx.doi.org/10.1016/j.joca.2010.03.006

52. Cosby NL, Hertel J. Clinical assessment of ankle injury outcomes: Case scenario using the foot and ankle ability measure. J Sport Rehabil. 2011;20(1):89-99. [PMID:21411825]

53. Farrugia P, Goldstein C, Petrisor BA. Measuring foot and ankle injury outcomes: Common scales and checklists. Injury. 2011;42(3):276-80. [PMID:21232744] http://dx.doi.org/10.1016/j.injury.2010.11.051

54. Niki H, Aoki H, Inokuchi S, Ozeki S, Kinoshita M, Kura H, Tanaka Y, Noguchi M, Nomura S, Hatori M, Tatsunami S. Development and reliability of a standard rating system for outcome measurement of foot and ankle disorders I: Development of standard rating system. J Orthop Sci. 2005;10(5):457-65. [PMID:16193356] http://dx.doi.org/10.1007/s00776-005-0936-2

55. Niki H, Aoki H, Inokuchi S, Ozeki S, Kinoshita M, Kura H, Tanaka Y, Noguchi M, Nomura S, Hatori M, Tatsunami S. Development and reliability of a standard rating system for outcome measurement of foot and ankle disorders II: Interclinician and intraclinician reliability and validity of the newly established standard rating scales and Japanese Orthopaedic Association rating scale. J Orthop Sci. 2005; 10(5):466-74. [PMID:16193357] http://dx.doi.org/10.1007/s00776-005-0937-1

56. Eechaute C, Vaes P, Van Aerschot L, Asman S, Duquet W. The clinimetric qualities of patient-assessed instruments for measuring chronic ankle instability: A systematic review. BMC Musculoskelet Disord. 2007;8:6. [PMID:17233912] http://dx.doi.org/10.1186/1471-2474-8-6 
57. Hale SA, Hertel J. Reliability and sensitivity of the foot and ankle disability index in subjects with chronic ankle instability. J Athl Train. 2005;40(1):35-40.

[PMID:15902322]

58. Martin RL, Irrgang JJ, Burdett RG, Conti SF, Van Swearingen JM. Evidence of validity for the Foot and Ankle Ability Measure (FAAM). Foot Ankle Int. 2005;26(11):968-83. [PMID:16309613]

59. Carcia CR, Martin RL, Drouin JM. Validity of the Foot and Ankle Ability Measure in athletes with chronic ankle instability. J Athl Train. 2008;43(2):179-83.

[PMID:18345343]

60. Wikstrom EA, Tillman MD, Chmielewski TL, Cauraugh JH, Naugle KE, Borsa PA. Self-assessed disability and functional performance in individuals with and without ankle instability: A case control study. J Orthop Sports Phys Ther. 2009;39(6):458-67. [PMID:19487824] http://dx.doi.org/10.2519/jospt.2009.2989

61. Donnery J, Spencer RB. The Biplane Goniometer. A new device for measurement of ankle dorsiflexion. J Am Podiatr Med Assoc. 1988;78(7):348-51. [PMID:3404411] http://dx.doi.org/10.7547/87507315-78-7-348

62. Rome K, Cowieson F. A reliability study of the universal goniometer, fluid goniometer, and electrogoniometer for the measurement of ankle dorsiflexion. Foot Ankle Int. 1996;17(1):28-32. [PMID:8821283] http://dx.doi.org/10.1177/107110079601700106

63. Bennell KL, Talbot RC, Wajswelner H, Techovanich W, Kelly DH, Hall AJ. Intra-rater and inter-rater reliability of a weight-bearing lunge measure of ankle dorsiflexion. Aust J Physiother. 1998;44(3):175-80. [PMID:11676731] http://dx.doi.org/10.1016/S0004-9514(14)60377-9

64. Croxford $\mathrm{P}$, Jones $\mathrm{K}$, Barker K. Inter-tester comparison between visual estimation and goniometric measurement of ankle dorsiflexion. Physiother Theory Pract. 1998; 14(2):107-13. http://dx.doi.org/10.3109/09593989809057153

65. Allington NJ, Leroy N, Doneux C. Ankle joint range of motion measurements in spastic cerebral palsy children: Intraobserver and interobserver reliability and reproducibility of goniometry and visual estimation. J Pediatr Orthop B. 2002;11(3):236-39. [PMID:12089500]

66. Munteanu SE, Strawhorn AB, Landorf KB, Bird AR, Murley GS. A weightbearing technique for the measurement of ankle joint dorsiflexion with the knee extended is reliable. J Sci Med Sport. 2009;12(1):54-59.

[PMID:17888733]

http://dx.doi.org/10.1016/j.jsams.2007.06.009

67. Kim PJ, Peace R, Mieras J, Thoms T, Freeman D, Page J. Interrater and intrarater reliability in the measurement of ankle joint dorsiflexion is independent of examiner experience and technique used. J Am Podiatr Med Assoc.
2011;101(5):407-14. [PMID:21957272]

http://dx.doi.org/10.7547/1010407

68. Krause DA, Cloud BA, Forster LA, Schrank JA, Hollman JH. Measurement of ankle dorsiflexion: A comparison of active and passive techniques in multiple positions. J Sport Rehabil. 2011;20(3):333-44. [PMID:21828385]

69. Konor MM, Morton S, Eckerson JM, Grindstaff TL. Reliability of three measures of ankle dorsiflexion range of motion. Int J Sports Phys Ther. 2012;7(3):279-87. [PMID:22666642]

70. O'Shea S, Grafton K. The intra and inter-rater reliability of a modified weight-bearing lunge measure of ankle dorsiflexion. Man Ther. 2013;18(3):264-68.

[PMID:23058447]

http://dx.doi.org/10.1016/j.math.2012.08.007

71. Sidaway B, Euloth T, Caron H, Piskura M, Clancy J, Aide A. Comparing the reliability of a trigonometric technique to goniometry and inclinometry in measuring ankle dorsiflexion. Gait Posture. 2012;36(3):335-39. [PMID:22607791] http://dx.doi.org/10.1016/j.gaitpost.2012.01.019

72. Topp R, Mikesky A. Reliability of isometric and isokinetic evaluations of ankle dorsi/plantar strength among older adults. Isokinet Exerc Sci. 1994;4(4):157-63.

73. Rose KJ, Burns J, Ryan MM, North KN. Reliability and validity of measuring foot and ankle muscle strength in very young children. Neuromuscul Disord. 2008;18(910): 741-42. http://dx.doi.org/10.1016/j.nmd.2008.06.062

74. Bénard MR, Jaspers RT, Huijing PA, Becher JG, Harlaar J. Reproducibility of hand-held ankle dynamometry to measure altered ankle moment-angle characteristics in children with spastic cerebral palsy. Clin Biomech (Bristol, Avon). 2010;25(8):802-8. [PMID:20541856] http://dx.doi.org/10.1016/j.clinbiomech.2010.04.010

75. Morris-Chatta R, Buchner DM, de Lateur BJ, Cress ME, Wagner EH. Isokinetic testing of ankle strength in older adults: Assessment of inter-rater reliability and stability of strength over six months. Arch Phys Med Rehabil. 1994;75(11):1213-16. [PMID:7979931] http://dx.doi.org/10.1016/0003-9993(94)90007-8

76. Kaminski TW, Perrin DH, Mattacola CG, Szczerba JE, Bernier JN. The reliability and validity of ankle inversion and eversion torque measurements from the Kin Com II isokinetic dynamometer. J Sport Rehabil. 1995;4(3):210-18.

77. Testerman C, Vander Griend R. Evaluation of ankle instability using the Biodex Stability System. Foot Ankle Int. 1999;20(5):317-21. [PMID:10353771] http://dx.doi.org/10.1177/107110079902000510

78. Holmbäck AM, Porter MM, Downham D, Lexell J. Ankle dorsiflexor muscle performance in healthy young men and women: Reliability of eccentric peak torque and work measurements. J Rehabil Med. 2001;33(2):90-96. 


\section{[PMID:11474955]}

\section{http://dx.doi.org/10.1080/165019701750098966}

79. DuPont L, Rabita G, Perot C, Thevenon A, Lensel-Corbeil G, Vanvelcenaher J. Isokinetics as a tool to assess instantaneous passive stiffness of spastic ankle joint. Isokinet Exerc Sci. 2002;10(1):47.

80. Aydoğ E, Aydoğ ST, Cakci A, Doral MN. Reliability of isokinetic ankle inversion- and eversion-strength measurement in neutral foot position, using the Biodex dynamometer. Knee Surg Sports Traumatol Arthrosc. 2004; 12(5):478-81. [PMID:15156307] http://dx.doi.org/10.1007/s00167-004-0530-8

81. Kim DY, Park CI, Chon JS, Ohn SH, Park TH, Bang IK. Biomechanical assessment with electromyography of post-stroke ankle plantar flexor spasticity. Yonsei Med J. 2005; 46(4):546-54. [PMID:16127781] http://dx.doi.org/10.3349/ymj.2005.46.4.546

82. Ordway NR, Hand N, Briggs G, Ploutz-Snyder LL. Reliability of knee and ankle strength measures in an older adult population. J Strength Cond Res. 2006;20(1):82-87. [PMID:16503696]

83. Holmbäck AM, Lexell J. Reproducibility of isokinetic ankle dorsiflexor strength and fatigue measurements in healthy older subjects. Isokinet Exerc Sci. 2007;15(4): 263-70.

84. Sekir U, Yildiz Y, Hazneci B, Ors F, Saka T, Aydin T. Reliability of a functional test battery evaluating functionality, proprioception, and strength in recreational athletes with functional ankle instability. Eur J Phys Rehabil Med. 2008;44(4):407-15. [PMID:19002090]

85. Yildiz Y, Şekir U, Hazneci B, Örs F, Saka T, Aydin T. Reliability of a functional test battery evaluating functionality, proprioception and strength of the ankle joint. Turk J Med Sci. 2009;39(1):115-23.

86. Araújo VL, Carvalhais VO, Souza TR, Ocarino JM, Gonçalves GG, Fonseca ST. Validity and reliability of clinical tests for assessing passive ankle stiffness. Rev Bras Fisioter. 2011;15(2):166-73. [PMID:21789368]

87. Flansbjer UB, Drake AM, Lexell J. Reproducibility of ankle dorsiflexor muscle strength measurements in individuals with post-polio syndrome. Isokinet Exerc Sci. 2011; 19(1):55-61.

88. Chesworth BM, Vandervoort AA. Reliability of a torque motor system for measurement of passive ankle joint stiffness in control subjects. Physiother Can. 1988;40(5): 300-303.

89. Kearney RE, Weiss PL, Morier R. System identification of human ankle dynamics: Intersubject variability and intrasubject reliability. Clin Biomech (Bristol, Avon). 1990;5(4): 205-17. [PMID:23916281] http://dx.doi.org/10.1016/0268-0033(90)90004-P
90. Weiss PL, Kearney RE, Morier R. Quantitative assessment of ankle joint dynamics during recovery from injury. Clin Biomech (Bristol, Avon). 1990;5(4):187-92. [PMID:23916278] http://dx.doi.org/10.1016/0268-0033(90)90001-M

91. Moseley A, Adams R. Measurement of passive ankle dorsiflexion: Procedure and reliability. Aust J Physiother. 1991;37(3):175-81. http://dx.doi.org/10.1016/S0004-9514(14)60540-7

92. Winegard KJ, Hicks AL, Vandervoort AA. Reliability of measuring voluntary strength and isometric twitch properties in the ankle muscles of very old adults. J Aging Phys Act. 1998;6(3):222-31.

93. Keating JL, Parks C, Mackenzie M. Measurements of ankle dorsiflexion in stroke subjects obtained using standardised dorsiflexion force. Aust J Physiother. 2000;46(3): 203-13. [PMID:11676804] http://dx.doi.org/10.1016/S0004-9514(14)60329-9

94. Loram ID, Lakie M. Direct measurement of human ankle stiffness during quiet standing: The intrinsic mechanical stiffness is insufficient for stability. J Physiol. 2002; 545(Pt 3):1041-53. [PMID:12482906] http://dx.doi.org/10.1113/jphysiol.2002.025049

95. Forster SM. A bilateral electro-hydraulic actuator system to measure dynamic ankle joint stiffness during upright human stance [thesis]. [Montreal, Canada]: McGill University; 2003.

96. Giacomozzi C, Cesinaro S, Basile F, De Angelis G, Giansanti D, Maccioni G, Masci E, Panella A, Paolizzi M, Torre M, Valentini P, Macellari V. Measurement device for ankle joint kinematic and dynamic characterisation. Med Biol Eng Comput. 2003;41(4):486-93. [PMID:12892374] http://dx.doi.org/10.1007/BF02348094

97. Wilken J, Saltzman C, Yack H. Reliability and validity of Iowa ankle range-of-motion device. J Orthop Sports Phys Ther. 2004;34:A17-18.

98. Ji Z, Findley T, Chaudhry H, Bukiet B. Computational method to evaluate ankle postural stiffness with ground reaction forces. J Rehabil Res Dev. 2004;41(2):207-14. [PMID:15558374] http://dx.doi.org/10.1682/JRRD.2004.02.0207

99. Peng Q, Shah P, Selles RW, Gaebler-Spira DJ, Zhang LQ. Measurement of ankle spasticity in children with cerebral palsy using a manual spasticity evaluator. Proceedings of the 26th Annual International Conference of the IEEE Engineering in Medicine and Biology Society; 2004 Sep 1-5; San Francisco, CA. p. 4896-99.

100. Casadio M, Morasso PG, Sanguineti V. Direct measurement of ankle stiffness during quiet standing: Implications for control modelling and clinical application. Gait Posture. 
2005;21(4):410-24. [PMID:15886131]

http://dx.doi.org/10.1016/j.gaitpost.2004.05.005

101. Schepers HM, Veltink PH. Estimation of ankle moment using ambulatory measurement of ground reaction force and movement of foot and ankle. Proceedings of the 1st IEEE/RAS-EMBS International Conference on Biomedical Robotics and Biomechatronics; 2006 Feb 20-22; Pisa, Italy. p. 399-401.

102. Nordquist J, Hull ML. Design and demonstration of a new instrumented spatial linkage for use in a dynamic environment: Application to measurement of ankle rotations during snowboarding. J Biomech Eng. 2007;129(2):231-39. [PMID:17408328]

103. Roy A, Krebs HI, Patterson SL, Judkins TN, Khanna I, Forrester LW, Macko RM, Hogan N. Measurement of human ankle stiffness using the anklebot. Proceedings of the IEEE 10th International Conference on Rehabilitation Robotics; 2007 Jun 13-15; Noordwijk, the Netherlands. p. 356-63.

104. Schepers HM, Koopman HF, Veltink PH. Ambulatory assessment of ankle and foot dynamics. IEEE Trans Biomed Eng. 2007;54(5):895-902. [PMID:17518287] http://dx.doi.org/10.1109/TBME.2006.889769

105. Zinder SM, Granata KP, Padua DA, Gansneder BM. Validity and reliability of a new in vivo ankle stiffness measurement device. J Biomech. 2007;40(2):463-67.

[PMID:16458900] http://dx.doi.org/10.1016/j.jbiomech.2005.12.007

106. Sung PS, Baek JY, Kim YH. Reliability of the intelligent stretching device for ankle stiffness measurements in healthy individuals. Foot (Edinb). 2010;20(4):126-32. [PMID:20951025] http://dx.doi.org/10.1016/j.foot.2010.09.005

107. Kobayashi T, Leung AK, Hutchins SW. Design of a manual device to measure ankle joint stiffness and range of motion. Prosthet Orthot Int. 2011;35(4):478-81.

[PMID:22013156] http://dx.doi.org/10.1177/0309364611425696

108. Peng Q, Park HS, Shah P, Wilson N, Ren Y, Wu YN, Liu J, Gaebler-Spira DJ, Zhang LQ. Quantitative evaluations of ankle spasticity and stiffness in neurological disorders using manual spasticity evaluator. J Rehabil Res Dev. 2011; 48(4):473-81. [PMID:21674395] http://dx.doi.org/10.1682/JRRD.2010.04.0053

109. Rouhani H, Favre J, Crevoisier X, Aminian K. Ambulatory measurement of ankle kinetics for clinical applications. J Biomech. 2011;44(15):2712-18.

[PMID:21851944] http://dx.doi.org/10.1016/j.jbiomech.2011.07.021

110. Wilken J, Rao S, Estin M, Saltzman CL, Yack HJ. A new device for assessing ankle dorsiflexion motion: Reliability and validity. J Orthop Sports Phys Ther. 2011;41(4):274-80.

\section{[PMID:21460462]}

http://dx.doi.org/10.2519/jospt.2011.3397

111. Fong DT, Chung MM, Chan YY, Chan KM. A mechanical jig for measuring ankle supination and pronation torque in vitro and in vivo. Med Eng Phys. 2012;34(6):791-94. [PMID:22472526] http://dx.doi.org/10.1016/j.medengphy.2012.03.004

112. Knight AC, Weimar WH. Development of a fulcrum methodology to replicate the lateral ankle sprain mechanism and measure dynamic inversion speed. Sports Biomech. 2012;11(3):402-13. [PMID:23072050] http://dx.doi.org/10.1080/14763141.2011.638724

113. Lorentzen J, Grey MJ, Geertsen SS, Biering-Sørensen F, Brunton K, Gorassini M, Nielsen JB. Assessment of a portable device for the quantitative measurement of ankle joint stiffness in spastic individuals. Clin Neurophysiol. 2012; 123(7):1371-82. [PMID:22119175]

http://dx.doi.org/10.1016/j.clinph.2011.11.001

114. Naito H, Akazawa Y, Miura A, Matsumoto T, Tanaka M. Identification of individual muscle length parameters from measurements of passive joint moment around the ankle joint. J Biomech Sci Eng. 2012;7(2):168-76. http://dx.doi.org/10.1299/jbse.7.168

115. Sefton GK, George J, Fitton JM, McMullen H. Reconstruction of the anterior talofibular ligament for the treatment of the unstable ankle. J Bone Joint Surg Br. 1979;61B(3):352-54. [PMID:113415]

116. Hunter IW, Kearney RE. Dynamics of human ankle stiffness: Variation with displacement amplitude. J Biomech. 1982;15(10):753-56. [PMID:7153228]

117. Hunter IW, Kearney RE. Dynamics of human ankle stiffness: Variation with mean ankle torque. J Biomech. 1982;15(10): 747-52. [PMID:7153227]

118. Siegler S, Moskowitz GD, Freedman W. Passive and active components of the internal moment developed about the ankle joint during human ambulation. J Biomech. 1984; 17(9):647-52. [PMID:6501324] http://dx.doi.org/10.1016/0021-9290(84)90118-0

119. Rome K. Ankle joint dorsiflexion measurement studies. A review of the literature. J Am Podiatr Med Assoc. 1996; 86(5):205-11. [PMID:8776155] http://dx.doi.org/10.7547/87507315-86-5-205

120. Wood DE, Burridge JH, van Wijck FM, McFadden C, Hitchcock RA, Pandyan AD, Haugh A, Salazar-Torres JJ, Swain ID. Biomechanical approaches applied to the lower and upper limb for the measurement of spasticity: A systematic review of the literature. Disabil Rehabil. 2005; 27(1-2):19-32. [PMID:15799142] http://dx.doi.org/10.1080/09638280400014683

Submitted for publication March 14, 2013. Accepted in revised form December 13, 2013. 
JRRD, Volume 51, Number 4, 2014

This article and any supplementary material should be cited as follows:

Zhang M, Davies TC, Zhang Y, Xie S. Reviewing effectiveness of ankle assessment techniques for use in robotassisted therapy. J Rehabil Res Dev. 2014;51(4):517-34. http://dx.doi.org/10.1682/JRRD.2013.03.0066
ResearcherID/ORCID: Shane Xie, Prof Eng PhD: K-8094-2012

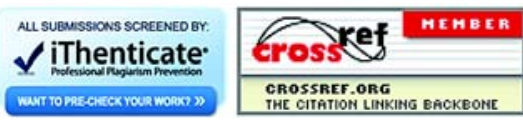

